
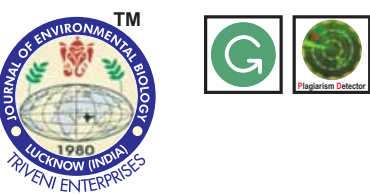

\title{
Influence of sowing depth and orientation on germination and seedling emergence of Cinnamomum tamala Nees
}

Authors Info

\section{B. Singh ${ }^{1 *}$, J.M.S. Rawat ${ }^{2}$ and Vivek Pandey,}

1 Department of Forestry, College of Forestry, VCSG UUHF Ranichauri Campus, Tehri Garhwal - 249 199, India

${ }^{2}$ Department of Horticulture, H.N.B. Garhwal University, Srinagar Garhwal - 246 174, India

${ }^{3}$ Department of Vegetable Science, College of Forestry, VCSG UUHF Ranichauri Campus, Tehri Garhwal - 249 199, India

${ }^{3}$ Regional Research Station, Punjab Agriculture University, Gurdaspur - 143 521, India

${ }^{*}$ Corresponding Author Email : butola_bs@yahoo.co.in

Key words

Biomass yield, Cinnamomum tamala

Germination index,

Orientation treatment,

Sowing depth

Publication Info

Paper received : 02.09 .2015

Revised received : 03.05.2016

Re-revised received : 17.06.2016

Accepted : 13.07.2016

\section{Abstract}

Aim: The effect of sowing depth and orientation on germination, seedling development and biomass yield of Cinnamomum tamala were studied. Buried depth and orientation is potentially important for successful germination and seedling development for regeneration.

Methodology: Seeds of $C$. tamala were sown at $3 \mathrm{~cm}, 5 \mathrm{~cm}$ and $7 \mathrm{~cm}$, buried in horizontal, upright and inverted orientation treatments.

Results: Fewer seeds were germinated as buried depth increased. Relative to buried at $3 \mathrm{~cm}$ and $5 \mathrm{~cm}$ depth, emergents were fewer and delayed for seeds buried at $7 \mathrm{~cm}$. Upright seed orientation enhanced germination relative to seeds sown in an inverted or horizontal orientation. Seed depth and orientation also affected germination time. Deeply buried seed significantly $(p<0.05)$ affected the shoot length, root length, number of leaves and their biomass allocation. Orientation treatment significantly $(p<0.05)$ impacted shoot and root length and their biomass allocation.

Interpretation: Seeds buried at shallow depths and upright orientation, were more favourable to seedling emergence and therefore, might play an important role in survival of newly emerged seedling of $C$. tamala.

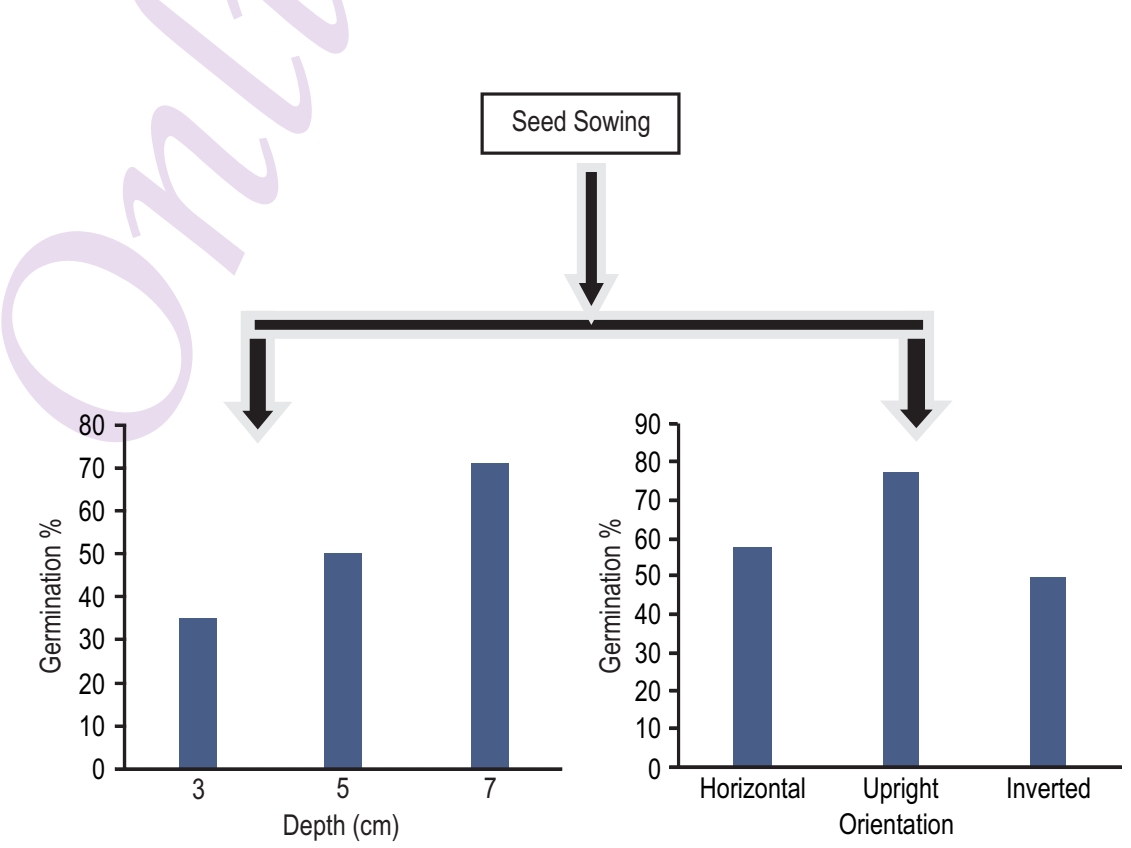




\section{Introduction}

The genus Cinnamomum is represented by about 350 species worldwide. Cinnamomum tamala Nees. (Lauraceae), commonly called Tejpat (trade name Tamalpatra), is an evergreen monoecious species and grows up to $8 \mathrm{~m}$ in height (Gaur, 1999). Its leaves are aromatic, astringent, stimulant, carminative qualities and traded as a spice tasting similar to cloves and scented similarly to pepper (De Minakshi, 1999; Anonymous, 2006; Dhar et al., 2002), and also as a source of various Ayurvedic and pharmaceutical preparations to treat rheumatism, colic, diarrhea, nausea, vomiting fever, anemia and body odour (Sarin, 2008). Its seeds are crushed and mixed with honey or sugar and administered to children for dysentery or cough (Chakraborty and Das, 2010). Collection of $C$. tamala leaves (one of the most commercially exploited medical plant from wild) is a source of livelihood for the people from interior villages of Asia. C. tamala is high medical value and also used as an important ingredient of the spices the demand of $C$. tamala is increasing day by day, and the species is being harvested illegally from its natural pockets (Samant et al., 2001; Sharma and Nautiyal, 2011).

Buried depth has an important effect on the fate of a seed (Benvenuti et al., 2001; Guo et al., 2001; Soltani et al., 2006). The shallower the seed is buried, the easier it may be found by predators. Suitable condition including temperature and humidity are necessary for seed germination, emergence and seedling recruitment (Michael and Paul, 2000; Kos and Poschlod, 2008). Deeply buried seeds have to invest more reserves into stem for their elongation before shoot apices can reach and emerge soil surface than seeds buried at shallower depths (Chen and Maun, 1999, Guo et al., 2001; Guo et al., 2009). Seed orientation, especially in large seeded species, influences seedling emergence both on the forest floor and in nursery seed beds (Prasad and Nautiyal, 2003). Seedling emergence in Bauhinia retusa is influenced by seed orientation in the nursery seed bed (Prasad and Nautiyal, 1995). Planting seeds of $B$. retusa in nurseries results in variable germination, while emergence from the forest floor is low (Prasad and Nautiyal, 1995).

Considering the economic potential and reduction in natural populations of $C$. tamala in subtropical regions, this species has been recommended for in-situ as well as ex-situ conservation (Samant et al., 2001; Sharma et al., 2009). Due to over-exploitation of $C$. tamala from their natural habitat, cultivation is being propagated. At present little work had been done to known germination pattern of this potential medicinal plant. Therefore, the objective of the present study develop a better knowledge of seed germination and seedling emergence as critical processes affecting seedling emergence and establishment in nursery for production of quality planting stock which is suitable for artificial as well as its natural regeneration. Therefore, the effects of buried depth and seed orientation on seed germination and early seedling growth of $C$. tamala was studied in pot in nethouse conditions.

\section{Materials and Methods}

Mature fruits of C. tamala were harvested from 10 phenotypically superior trees from the Devtal area $\left(30^{\circ} 23^{\prime} \mathrm{N}\right.$, $79^{\circ} 19^{\prime}$ E; 1850 m a. s. I.) in Rudraprayag district, on 7th April, 2012 and 2013. Seeds were excised from fruits and cleaned under running tap water and then allowed to dry in aerated shade for 48 hrs.

Sowing depth : Three days after seed collection five replicates of 100 seeds each were placed (radical end down) at $3-\mathrm{cm}, 5-\mathrm{cm}$ and $7-\mathrm{cm}$ depth in root trainers. The root trainers were $6 \mathrm{~cm}$ in diameter and $19.5 \mathrm{~cm}$ in depth. The substrate in the root trainer was a mixture of compost and river sand at a volumetric proportion of about $1: 2$. The root trainers were placed on stands in a greenhouse at seed collection site. They were watered daily for saturation. In greenhouse, average temperature for successive two year ranged from $8.5^{\circ} \mathrm{C}$ to $26.6^{\circ} \mathrm{C}$. Seedling emergence was monitored daily until no further emergence was observed. After 120 days of sowing, ten individual seedlings per replicate were randomly uprooted at successive two years. Data were pooled for the presenting results.

Seedling height and root length (after washed) were measured by meter scale. Collar diameter was measured using a micrometer (Besto make). Number of leaves was calculated by simple counting. Biomass was determined by separating each harvested seedling into roots, shoot, leaves, and the remains of the seed (Cotyledons) and these parts oven drying for $48 \mathrm{hr}$ at $98 \pm 2^{\circ} \mathrm{C}$ till constant to obtain the biomass.

At the time of harvest, four developmental stages were recognized: non-germinated seed (dead seeds cotyledons), radicle seedling (with the root but without stem) non-emerged seedling (with only below ground part of the stem) and emerged seedling.

Seed sowing orientation : Seeds of $C$. tamala were divided into three groups with respect to sowing orientation in a randomized block design: (i) micropyle end up (inverted); (ii) micropyle end down (upright); and (iii) radical parallel to the soil surface (horizontal). Five replicates of 100 seeds for each treatment were buried in substrate with depth of 3-cm in root trainers. In seed orientation treatments, root trainer volume, potting substrate, irrigation protocols were similar to buried treatment. Germination and growth data were also recorded as described above.

Mean germination time : For each experiment, mean germination time (MGT) was calculated using the following equation (Ellis and Roberts, 1981).

$$
M G T=\Sigma D n / \Sigma n
$$

Where, $n$ is the number of seeds that germinated on day $D$, and $D$ is the number of days calculated from the beginning of the test. 
Table 1 : Effect of different burying depth and orientation treatments on germination results of Cinnamomum tamala

\begin{tabular}{lllll}
\hline Depth $(\mathrm{cm})$ & Emerged seedling & Non-emerged seedling & Radicle seedlings & Non-geminated seeds \\
\hline 7 & $35.00 \pm 5.77^{\mathrm{c}}$ & $29.00 \pm 8.16^{\mathrm{a}}$ & $18.00 \pm 5.00^{\mathrm{a}}$ & $18.00 \pm 9.57^{\mathrm{a}}$ \\
5 & $50.00 \pm 3.54^{\mathrm{b}}$ & $22.00 \pm 2.74^{\mathrm{ab}}$ & $15.00 \pm 3.54^{\mathrm{ab}}$ & $13.00 \pm 5.7^{\mathrm{a}}$ \\
3 & $71.00 \pm 6.63^{\mathrm{a}}$ & $14.00 \pm 3.74^{\mathrm{b}}$ & $7.00 \pm 4.00^{\mathrm{b}}$ & $8.00 \pm 2.45^{\mathrm{b}}$ \\
Orientation & & & & \\
Horizontal & $58.00 \pm 7.58^{\mathrm{b}}$ & $20.00 \pm 3.54^{\mathrm{a}}$ & $9.00 \pm 5.48^{\mathrm{b}}$ & $13.00 \pm 4.47^{\mathrm{a}}$ \\
Upright & $77.00 \pm 6.71^{\mathrm{a}}$ & $16.00 \pm 4.18^{\mathrm{a}}$ & $0.00 \pm 0.00^{\mathrm{c}}$ & $8.00 \pm 2.74^{\mathrm{a}}$ \\
Inverted & $50.00 \pm 6.12^{\mathrm{b}}$ & $18.00 \pm 7.58^{\mathrm{a}}$ & $17.0 \pm 4.47^{\mathrm{a}}$ & $15.00 \pm 5.00^{\mathrm{a}}$ \\
\hline
\end{tabular}

Within each treatments, value marked by the same letter are not significantly $(p<0.05)$ different, \pm SE

Germination index : Germination index (GI) was calculated as described by Kendrick and Frankland (1969).

$$
\text { Germination index }=\frac{\text { Total percent germination }}{\text { Time (days) taken for } 50 \% \text { germination }}
$$

Statistical analysis : At different burying depth and orientation treatments, seedling emergence and biomass production were statistically analyzed by using SPSS software package, version 10.0.1 (SPSS Inc., Chicago, USA) for two way analysis of variance and Tukey (HSD) test was used for statistical analysis.

\section{Results and Discussion}

Seed buried depth : Seedling emergence of Cinnamomum tamala was best in the shallower burying depth $(3 \mathrm{~cm})$ and worst in the deeply buried depth $(7 \mathrm{~cm})$ treatment (Table 1). Seed buried at $3 \mathrm{~cm}$ depth, $8.0 \%$ seed did not germinate, while about 13.0 and $18.0 \%$ seeds buried at $5 \mathrm{~cm}$ and $7 \mathrm{~cm}$ depth did not germinate. At $3 \mathrm{~cm}$ and $5 \mathrm{~cm}$ burying depth, 71.0 and $50.0 \%$ seedlings successfully emerged, but only 35.0 percent seedling emerged from $7 \mathrm{~cm}$ depth. Deeply buried seeds usually emerge later than those that are shallow buried (John and Sullivan, 2013). Ali and Idris (2015) also reported that Seed germination of Vicia faba other parameters increased with the decreasing sowing depth. A similar study conducted by Uniyal et al. (2007) revealed that shallow buried (at soil surface) seeds of Azadirachta indica germinated to a higher percentage, and the seedlings emerged earlier than those that were deeply buried at $5 \mathrm{~cm}$ depth.

In contrast, many seedlings from the seeds buried at the 3 $\mathrm{cm}, 5 \mathrm{~cm}$, and $7 \mathrm{~cm}$ depth remained at developmental stage of non emerged seedlings. A different burying depth some seed produced root, but they failed to produce shoot (Table 1). Dry weight of seed remains at the harvest date tended to be lower for seedling that were more developed. The weight was significantly affected by the developmental stage and interaction between stage and burying depth (Fig. 1).

Seedlings tended to emerge earlier with decrease in burying depth (Fig. 2 and 3). Seeds buried at $3 \mathrm{~cm}, 5 \mathrm{~cm}, 7 \mathrm{~cm}$ depth, on average took $39,44,50$ days, respectively to emerged

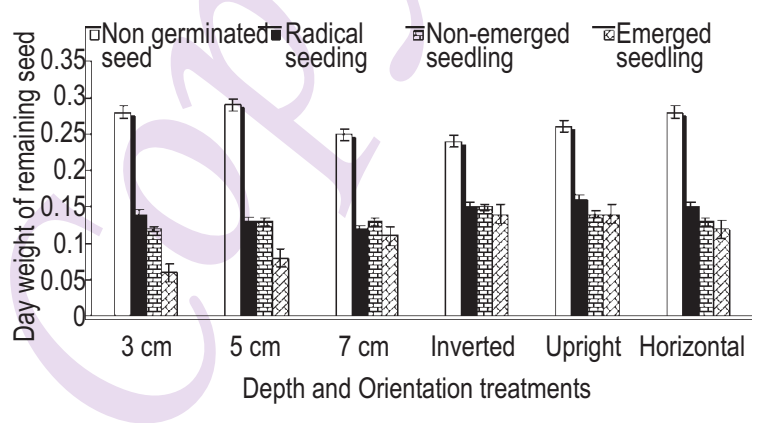

Fig. 1 : Dry weight of per remained seeds ( $\mathrm{g}$ ) at different developmental stage of each burying and orientation of Cinnamomum tamala (Vertical bars represent $\pm S E$ ); Value marked by the same letter are not significantly $(p<0.05)$ different in each treatment within different seedling developmental stage

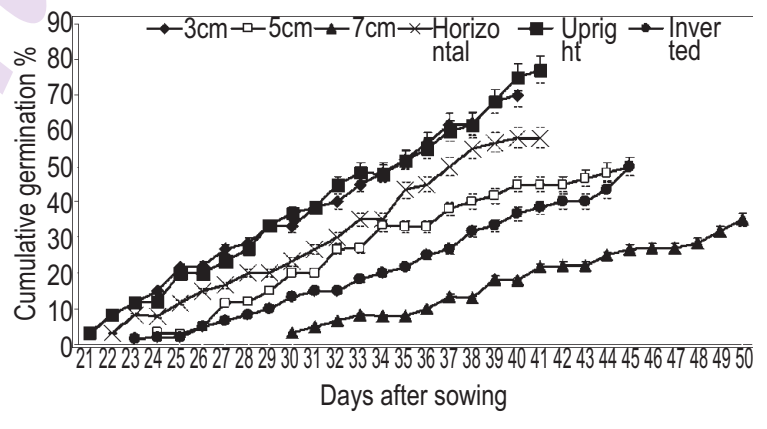

Fig. 2 : Cumulative germination percentage of emerged seedling of Cinnamomum tamala

(Fig. 2). The mean germination time and germination index significantly $(p<0.05)$ varied with depth treatments. The mean germination time for seedling emergence at $3 \mathrm{~cm}, 5 \mathrm{~cm}$ and $7 \mathrm{~cm}$ depth treatment was 29,32 and 43 days respectively. Similarly, germination index also varied with burying treatments. Seeds buried at $3 \mathrm{~cm}$ depth treatment produced 33.0 and $61.0 \%$ greater germination index as compared to $5 \mathrm{~cm}$ and $7 \mathrm{~cm}$ depth treatments, respectively (Fig. 2).

ANOVA showed that emergence seedling percentage was significantly $(p<0.01)$ affected by burial depth and interaction 
between burial depth and orientation treatment (Table 3). Burying depths with their interaction and orientation significantly $(p<0.01)$ affected shoot length, root length number of leaves/plant. The number of leaves/plant were maximum (6.47) at $3 \mathrm{~cm}$ depth treatment and minimum (4.72) at $7 \mathrm{~cm}$ depth treatment. Biomass of different components was also significantly $(p<0.05)$ affected by the burying depth and interaction with orientation (Table 2 and 3 ).

In other words, deeply buried seeds might suffer from rotting due to higher soil humidity in deeper soil zone than that in shallower (Guo et al., 2010). Soil water saturation over prolonged period of time generates a negative impact on nearly all the terrestrial plants, as a consequence of slow diffusion rates of gases in water (Armstrong, 2002), which hampers oxygen supply to roots and reduces respiration and photosynthesis rates (Voesenek et al., 2006). Ahirwar et al. (2015) reported that seed of Butea frondosa germinated better at $2 \mathrm{~cm}$ depth and germination percentage gradually decreased with increase in sowing depth. The results of present study are agreement with this earlier study. Mohammad (2011) reported that field bindweed seeds emerged from up to $6 \mathrm{~cm}$ depth. But the results of present study seeds emerged upto $7 \mathrm{~cm}$ depth.

Depletion (consumption) of seed reserves depends on the seedling developmental stage rather than on burying depth (Maun and Riach, 1981). The present study is in conformity with the earlier study, which reveals that remaining seed weight could be varied significantly $(p<0.05)$ with seedling development stage as compared to the seed depth. Ren et al., (2002) working on Calligonum L. species suggested that the deeper the seeds in sand, the lower and slower their germination and seedling emergence. The same author indicated that the percent seedling emergence, number of days to first emergence, percent seed germination and percent of dormant seeds were significantly affected by burial depth and differed among Calligonum L. species, which is in agreement with the present findings. Seeds of Nitraria phaerocarpa artificially planted at different depths had significantly affected percent seedling emergence, seedling mass and seedling height. The emergence of seedling was highest at the optimal burial depth of $2 \mathrm{~cm}$, and decreased with increasing burial depth (Li et al., 2006). In the present study, seedling height and root length significantly $(p<0.05)$ varied with seed sowing depth. Similarly, shoot and root biomass also varied significantly $(p<0.05)$ with seed sowing depth. These results are in conformity with the finding of Seiwa et al., (2002) which revealed that seedling emergence, seedling mass and height were usually reduced by deep burial in Castanea crenata Sieb. et Zucc. with increasing burial depth the biomass allocation to stems increased, while allocation to roots decreased. Such morphological changes would amortize the limited seed reserve to facilitate emergence.

At $5 \mathrm{~cm}$ and $7 \mathrm{~cm}$ depth treatment several seedlings remained at the non-emerged and radicle seedlings stage. These

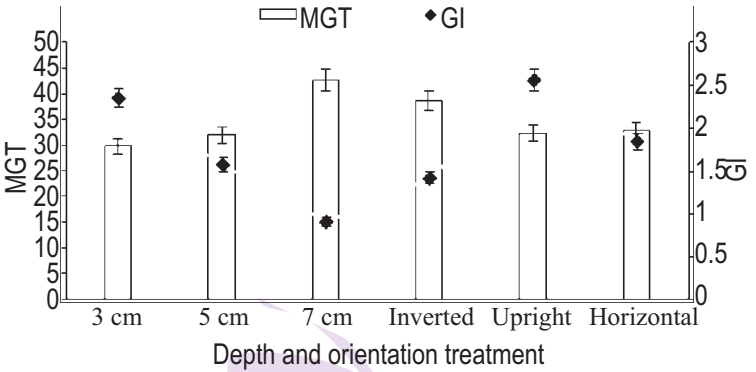

Fig. 3 : Mean germination time (MGT) and germination index (GI) at different burying depth and orientation of Cinnamomum tamala (Vertical bars represent $\pm S E$ ); Value marked by the same letter are not significantly $(p<0.05)$ different in depth and orientation treatment; mean germination time denoted by small letters and germination index by capital letters

types of seedlings have difficulties to emerge above ground, because their main stem tips had been frequently replaced or the seedlings were not capable to produce stem. Some stems of the seedlings grew with more than one branch simultaneously (multistemmed) below ground.

Seed sowing depth is important for seedling to successfully establish in nature. For $C$. tamala, $7 \mathrm{~cm}$ depth often seems to be too deep for seed germination and for seedling development. The initial height of the species were determined by the movement when the first whirl of leaves flushes. On the belowground part of the stems, many nodes can be seen on which the leaves should have flushed had the nodes been exposed aboveground (Gao, 1999). This suggested that flushing of leaves cannot start until the shoot emerges aboveground. When the leaves flush, most nutrient and carbohydrates from the reserves (even some from the stem) is transferred to the developing leaves and stem growth is temporarily limited but does not completely stop. These constraints may explain that the initial height might not be affected by burying depth (at least as long as the cotyledons still carry sufficient reserves to maintain stem growth) (Guo, 1999).

Seed orientation : In upright treatment $7.0 \%$ seeds did not germinate, while at horizontal and inverted orientation 13.0 and $15.0 \%$ seeds did not germinate. At upright orientation treatment, $77.0 \%$ seedlings were successfully emerged. But only 50.0 and $58.0 \%$ seedling emerged at horizontal and inverted orientation (Table 1). The present study effects of seed orientation presented that seed sowing in upright position give best results in term of germination and growth. However, it can be concluded that the results are crop-specific or species specific based on the finding of Prasad and Nautiyal (1995) in Bauhinia retusa; Prasad and Nautiyal, (2003) in Bauhinia vahlli and B. racemosa; Agboola et al. (1993) in Tectona grandis and Ceiba pentandra; Rawat and Nautiyal (1998) in Quercus leucotrichophora. 
Table 2 : Effect of burying depth and orientation on seedling growth and biomass at harvesting stages of Cinnamomum tamala

\begin{tabular}{|c|c|c|c|c|c|c|c|c|}
\hline Treatments & $\begin{array}{l}\text { Shoot } \\
\text { length } \\
\text { (cm) }\end{array}$ & $\begin{array}{l}\text { Root } \\
\text { length } \\
\text { (cm) }\end{array}$ & $\begin{array}{l}\text { Collar } \\
\text { diameter } \\
(\mathrm{mm})\end{array}$ & $\begin{array}{l}\text { Number of } \\
\text { Leaves/Plant }\end{array}$ & $\begin{array}{l}\text { Shoot dry } \\
\text { weight } \\
\text { mg/plant }\end{array}$ & $\begin{array}{l}\text { Root dry } \\
\text { weight } \\
\text { mg/plant }\end{array}$ & $\begin{array}{l}\text { Leaves dry } \\
\text { weight } \\
\text { mg/plant }\end{array}$ & $\begin{array}{l}\text { Total dry } \\
\text { weight } \\
\text { mg/plant }\end{array}$ \\
\hline \multicolumn{9}{|l|}{ Depth } \\
\hline $3 \mathrm{~cm}$ & $11.93 \pm 0.69^{a}$ & $8.58 \pm 0.23^{\mathrm{a}}$ & $1.72 \pm 0.09^{a}$ & $6.47 \pm 0.27^{\mathrm{a}}$ & $607 \pm 51^{a}$ & $522 \pm 25^{\mathrm{a}}$ & $1517 \pm 126^{a}$ & $2645 \pm 97^{\mathrm{a}}$ \\
\hline $5 \mathrm{~cm}$ & $11.17 \pm 0.88^{b}$ & $7.83 \pm 0.28^{\mathrm{a}}$ & $1.66 \pm 0.04^{\mathrm{a}}$ & $4.91 \pm 0.67^{b}$ & $501 \pm 43^{b}$ & $403 \pm 47^{b}$ & $1226 \pm 92^{b}$ & $2130 \pm 97^{b}$ \\
\hline $7 \mathrm{~cm}$ & $10.88 \pm 1.16^{c}$ & $6.15 \pm 1.03^{b}$ & $1.64 \pm 0.03^{\mathrm{a}}$ & $4.72 \pm 0.49^{b}$ & $508 \pm 60^{\mathrm{a}}$ & $401 \pm 35^{b}$ & $1014 \pm 73^{b}$ & $1923 \pm 43^{b}$ \\
\hline \multicolumn{9}{|l|}{ Orientation } \\
\hline Horizontal & $11.31 \pm 0.37^{\mathrm{a}}$ & $8.62 \pm 0.54^{b}$ & $1.62 \pm 0.21^{\mathrm{a}}$ & $5.78 \pm 0.19^{\mathrm{a}}$ & $505 \pm 32^{a}$ & $403 \pm 55^{b}$ & $1400 \pm 39^{b}$ & $2308 \pm 117$ \\
\hline Upright & $11.71 \pm 1.70^{\mathrm{a}}$ & $9.63 \pm 0.34^{a}$ & $1.72 \pm 0.08^{\mathrm{a}}$ & $6.44 \pm 0.69^{\mathrm{a}}$ & $509 \pm 49^{a}$ & $500 \pm 88^{a}$ & $1542 \pm 103^{b}$ & $2551 \pm 143$ \\
\hline Inverted & $10.99 \pm 1.38^{\mathrm{a}}$ & $9.01 \pm 0.28^{\mathrm{ab}}$ & $1.65 \pm 0.08^{\mathrm{a}}$ & $6.22 \pm 0.19^{\mathrm{a}}$ & $406 \pm 56^{a}$ & $504 \pm 62^{\mathrm{a}}$ & $1607 \pm 41^{\mathrm{a}}$ & $2513 \pm 81^{a}$ \\
\hline
\end{tabular}

Within each treatments, value marked by the same letter are not significantly $(p<0.05)$ different, values are mean $\pm S E$

Table 3: Analysis of variance with seed sowing depth and orientation treatment

\begin{tabular}{lllllllllllll}
\hline Treatment & \multicolumn{10}{c}{ F-value for seed germination and seedling growth characteristics } \\
\hline & 1 & 2 & 3 & 4 & 5 & 6 & 7 & 8 & 9 & 10 & 11 & 12 \\
Depth & $53.03^{* *}$ & $10.56^{* *}$ & $9.24^{* *}$ & $4.56^{*}$ & $4.91^{*}$ & $11.57^{* *}$ & 1.22 & $10.75^{* *}$ & $4.65^{*}$ & $8.13^{*}$ & $15.0^{* *}$ & $42.99^{* *}$ \\
Orientation & $20.61^{* *}$ & 0.68 & $21.70^{* *}$ & 3.71 & $3.85^{*}$ & $5.06^{*}$ & 0.31 & 1.87 & $3.86^{*}$ & $4.56^{*}$ & $6.60^{*}$ & $3.86^{*}$ \\
\hline
\end{tabular}

Abbreviation: 1= Emerged seedling; 2= Non-emerged seedling; $3=$ Radicle seedlings; $4=$ Non geminated seeds; $5=$ Shoot length (cm); $6=$ Root length (cm); $7=$ Collar diameter $(\mathrm{mm}) ; 8=$ Number of leaves $/$ plant; $9=$ Shoot dry weight $\mathrm{mg} / \mathrm{plant} ; 10=$ Root dry weight $\mathrm{mg} /$ plant; $11=$ Leaves dry weight mg $/$ plant; $12=$ Total dry weight $\mathrm{mg} / \mathrm{plant} ;{ }^{* *}$ Significant at $p<0.01,{ }^{*}$ Significant at $p<0.05$ level

Seedlings from different orientation treatments remained at the developmental stage of non-emerged seedlings. In orientation treatments, dry weight of seed remains (remaining cotyledon) at the harvest date was lower in seedlings which were more developed (Fig. 2).

Seeds oriented at different position took 41 to 45 days to complete the germination (Fig.2). The mean germination time was significantly $(p<0.05)$ lower at upright and horizontal orientation as compared to the inverted orientation. Germination index varied with different orientation treatments. Seeds oriented at upright treatment exhibited 28.0 and $45.0 \%$ greater germination index as compared to the horizontal and inverted orientation respectively (Fig. 3).

ANOVA showed that emergence seedling percentage was significantly $(p<0.01)$ affected by seed orientation and interaction with burying depth (Table 2 and 3). Orientation treatment and their interaction with burying depth was significantly $(p<0.01)$ affected by shoot length, root length, and number of leaves, and their biomass allocation (Table 2 and 3 ).

It is interesting to see that reaming seed weight was not affected by orientation, it influenced by the seedling developmental stage (Fig. 1). Three necessary factors i.e. appropriate temperature; oxygen and humidity are required for seed germination, emergence and seedling recruitment (Michael and Paul, 2000; Kos and Poschlod, 2007). The variance in germination and seedling recruitment in different sowing depth in the present study might be influenced by these factors which are required for seed germination and seedling growth. These factors might vary among different burial depths. In another study, under optimal configuration between sunshine and temperature, seeds would germinate better and more seedlings were established successfully (Guo et al., 2010). This could be region behind the non-germinated seed was higher at $7 \mathrm{~cm}$ depth in the present study. Hence, if a seed failed to germinate, the energy contained within the seeds is eventually lost because of respiration during subsequent residence time in soil (Finch-Savage, 1995). The result of the present study showed that seed burying at $3 \mathrm{~cm}$ depth had uniformly, faster and higher seedling emergence, as well as higher growth and biomass production, which indicated favourite micro-environment for seed germination and seedling growth, and development of $C$. tamala was might be at the $3 \mathrm{~cm}$ sowing depth. While, seed orientation treatment produced mixed response, so any conclusion related to seed orientation treatment predicting is not possible in present study. The effects of orientation on seed germination and seedling growth with biomass allocation on C. tamala needs further research.

\section{References}

Agboola, D.A., E.O. Etejere and M.O. Fawole: Effect of orientation and soil types on germination of seed tropical forest tree species. Seed Res., 21, 13-20 (1993).

Anonymous: Statistical Abstract. National School of Agricultural 
Marketing. A Govt. of India Organization- Ministry of Agriculture, Jaipur, India (2006).

Ali, S.A.M. and A.Y. Idris: Effect of seed size and sowing depth on germination and some growth parameters of Faba bean (Vicia faba.). Agricul. Biol. Sci., 1, 1-5 (2015).

Armstrong, W. and drew C Malcolm: Root growth and metabolism under oxygen deficiency. In: Plant Roots: The Hidden Half (Eds.: Y. Waisel, A. Eshel and U. Kafkafi). New York, Marcel Dekker Publishers, pp. 729-761 (2002).

Asgharipou, Mohd.R.: Effects of planting depth on germination and the emergence of field Bindweed (Convolvulus arvensis L.). Asian J. Agri. Sci., 3, 459-461 (2011).

Ahirwar R.K.: Effect of sowing depth on seed germination of Butea frondosa (Roxb.). Inter. Res. J. Bio. Sci., 4, 45-47 (2015).

Benvenuti, S., M. Macchia and S. Miele: Light, temperature and burial depth effects on Rumex obtusifolius seed germination and emergence. Weed Res., 41, 177-186 (2001).

Chakraborty, U. and H. Das: Antidiabetic and antioxidant activities of Cinnamomum leaf extracts in stz-treated diabetic rats. Glob. J. Biot. Biochem., 5, 12-18 (2010).

Chen, H. and M.A. Maun: Effect of sand burial depth on seed germination and seedling emergence of Cirsium pitcheri. Plant Ecology, 140, 53-60 (1999).

De, Minakshi., A. Krishna. De and A.B. Banergee: Antimicrobial screening of some Indian spices. Phytotherapy Res., 13, 616-618 (1999).

Dhar, U., S. Manjkhola, M. Joshi, A. Bhatt, A.K. Bisht and M. Joshi: Current status and future strategy for development of medicinal plant sector in Uttaranchal, India. Current Sci., 83, 956-963 (2002).

Ellis, R.H. and E.H. Roberts: The quantification of ageing and survival in orthodox seeds. Seed Sci. Tech., 9, 373-409 (1981).

Finch-Savage, W.E.: Influence of seed quality on crop establishment, growth, and yield. In: Seed quality: Basic mechanisms and agricultural implications (Ed.: A.S. Basra). Food Products Press. New York, pp. 361-384 (1995).

Gaur, R.D.: Flora of District Garhwal, North West Himalaya, With Ethnobotanical Notes. Trans Media, Srinagar Garhwal, Uttarakhand, India (1999).

Guo, Ke: Seedling performance of dominated tree species in Chinese Beech Forests. pp. 119 (1999).

Guo, C., Z.L. Wang and J. Lu: Seed germination and seedling development of Prunus armeniaca under different burial depths in soil. J. Forest Res., 21, 492-496 (2010).

Guo, C., J. Lu. D. Yang and L. Zhao: Impacts of burial and insect infection on germination and seedling growth of acorns of Quercus variabilis. For. Ecol Man., 258, 1497-1502 (2009).

Guo, Ke., R. Li and M.J.A. Werger: Effect of acorn burying depth on germination, seedling emergence and development of Quercus aliena var. acuteserrata. Acta Bot. Sin., 43, 974-978 (2001).

Kendrick, R.E. and B. Frankland: Photocontrol of germination in Amaranthus caudatus. Planta, 85, 326-329 (1969).

Kos, M. and P. Poschlod: Seeds use temperature cues to ensure germination under nurse-plant shade in Xeric Kalahari Savannah. Ann. Bot., 99, 667-675 (2007).

Li, Q.Y., W.Z. Zhao and H.Y. Fang: Effects of sand burial depth and seed mass on seedling emergence and growth of Nitraria sphaerocarpa. Plant Ecol., 185, 191-198 (2006).

Maun, M. A. and S. Riach: Morphology of caryopses, seedlings and seedling emergence of the grass Calamovilfa longifolia from various depths in sand. Oecologia, 49, 37-142 (1981).

Michael, P.D and B.C. Paul: Effects of wetting and drying on seed germination and seedling emergence of bull thistle, Cirsium vulgare (Savi) Ten. Canadian J. Bot., 78, 1545-1551 (2000).

Prasad, P. and A.R. Nautiyal: Influence of seed orientation on seedling emergence in Bauhinia retusa Ham. Ex. Roxb. Seed Sci. Tech., 20, 861-864 (1995).

Prasad, P. and A.R. Nautiyal: Effect of orientation of seed placement in soil on seedling emergence in two Bauhinia species: Bauhinia vahlii Wight et Arn. and Bauhinia racemosa Lam. Seed Sci. Tech., 31, 497-503 (2003).

Proctor, J.T.A. and J.A. Sullivan: Effect of seeding depth on seedling growth and dry matter partitioning in American ginseng. J. Ginseng Res., 37, 254-260 (2013).

Rawat, D.C.S. and A. R. Nautiyal: Physiology of germination in Quercus .Il. Effect of seed orientation in Quercus leucotrichophora. Seed Res., 26, 183-186 (1998).

Ren, J., L. Tao and X.M. Liu: Effects of sand depth on seed germination and seedling emergence of Calligonum L. species. J. Arid Environ., 51, 603-611 (2002).

Samant, S.S., U. Dhar and L.M.S. Paln: Himalayan medicinal plants: potential and prospects. Himavikas Occasional Publication No. 14. G.B. Pant Institute of Himalayan Environment and Development. Kosi-Katarmal, Almora (2001).

Seiwa, K., A. Watanabe, T. Saitoh, T. Kannu and S. Akasaka: Effects of burying depth and seed size on seedling establishment of Japanese chestnuts, Castanea crenata. Forest Ecol. Manage., 164, 149-156 (2002).

Sharma, G., B.P. Nautiyal and A.R. Nautiyal: Seedling emergence and survival in Cinnamomum tamala under varying micro-habitat conditions: Conservation implications. Trop. Ecol., 50, 201-209 (2009).

Sharma, G. and A. R. Nautiyal: Cinnamomum tamala: A valuable tree from Himalayas. Int. J. Med. Arom Plants, 1, 1-4 (2011).

Sarin, Y.K.: Principal crude herbal drugs of India. Bishen Singh Mahendra Pal Singh, Dehra Dun (2008).

Soltani, A., M.J. Robertson, B. Torabi and M. R. Sarparast Yousefi-Daz : Modelling seedling emergence in chickpea as influenced by temperature and sowing depth. Agric. For. Meteorol., 38,156-167 (2006).

Uniyal, A.K., B. Singh and N.P. Todaria: Effect of seed size, sowing orientation and depth on germination and seedling growth in neem, Azadirachta indica. Seed Tech., 29, 68-75 (2007).

Voesenek, L.A.C.J., T.D. Colmer, R. Plerik, F.F. Millenaar and A.J.M. Peeters: How plant cope with complete submergence. New Phytol., 170, 213-226 (2006). 